\title{
S5ynthesis
}

International Scientific Conference of IT and Business-Related Research

\section{THE USE OF SELECTION METHODS IN HOSPITALITY}

\section{UPOTREBA METODA SELEKCIJE U HOTELSKOJ INDUSTRIJI}

\author{
Teodora Rebić ${ }^{1}$, Lazar Dražeta ${ }^{2}$, Borivoje Đokić ${ }^{3}$ \\ ${ }^{1}$ IMC Krems \& Singidunum University, 32 Danijelova St., Belgrade, Serbia \\ ${ }^{2}$ Singidunum University, 32 Danijelova St., Belgrade, Serbia \\ ${ }^{3}$ Keiser University, Fort Lauderdale, Florida, USA
}

\begin{abstract}
:
Given the fact that human capital is one of the major sources of competitive advantage of each and every organization, it is of vital importance to determine the extent to which selection methods are effective in terms of choosing quality staff. The main aim is to establish positive correlation between job requirements and candidate's competences and qualifications, so as to retain the best candidates. The purpose of this work is to examine employee selection methods during the hiring process and investigate possible differences between different ranking hotels. The survey was carried out in a number of three, four and five-star hotels in Belgrade city region using both qualitative and quantitative questions as well as interviews with the human resources professionals. The rationale behind research was to compare selection methods utilized by different hotel rating categories and investigate their effectiveness in terms of employee placement, regarding both managerial and non-managerial positions.
\end{abstract}

\section{Key words:}

human capital, selection methods, hospitality, survey.

\section{INTRODUCTION}

Unlike other business assets, human capital represents a large operating cost while it is the only value that cannot be owed by any organization (Bhutoria, 2006). Historical evolution of S\&P 500 companies shows a significant change between their market and book value, having intangible assets (i.e. products and services created by employees) increased by five fold over the past 40 years (Ocean Tomo, 2010). Hence, employees can be seen as a major source of competitive advantage and renewable talent pool to make business sustainable.

This is of particular importance in services industry, such as hospitality, where quality of service provided to the customers determines contemporary hotel rating (Hensens et al., 2010). Key asset that enables it are employees, assigned through the selection process to vacancies to improve organizational performance (Torrington et al., 2014). This kind of strategic approach to selection requires effective criteria of evaluating selection methods through (Noe et al., 2007; Dessler, 2012):

- Reliability: the extent to which a measurement is free from random error, thus generating consistent results when repeated;

- Validity: the extent to which performance on the measure is related to what is designed to assess, thus representing a proper predictor of candidates' subsequent job performance.

\section{Apstrakt:}

Obzirom da je ljudski kapital jedan od osnovnih izvora konkurentne prednosti svake organizacije, od vitalnog je značaja da se utvrdi do koje mere su metode selekcije zaposlenih efektivne po pitanju odabira kvalitetnog osoblja. Cilj je da se ostvari podudarnost između zahteva radnog mesta sa jedne i kvalifikacija i sposobnosti kandidata sa druge strane, kako bi se u organizaciji zadržali najbolji kandidati. Svrha ovog rada je da se razmotre metode selekcije tokom procesa zapošljavanja i da se istraže eventualne razlike izmedju praksi hotela različitih kategorija. Sprovedena je anketa sa kvantitativnim i kvalitativnim pitanjima, kao i intervjuu sa zaposlenima iz sektora ljudskih resursa u beogradskim hotelima sa tri, četiri i pet zvezdica. Ovim istraživanjem su upoređene metode selekcije koje koriste hoteli različitih kategorija, kao i efektivnost istih u odabiru zaposlenih, kako za rukovodeće, tako i za pozicije hotelskog osoblja.

\section{Ključne reči:}

ljudski kapital, metode selekcije, hotelijerstvo, anketa.

Numerous selection techniques are devised to meet these criteria. For the purpose of this study, we defined 20 different techniques grouped within three selection methods: tests, interviews and assessment centre. Given the fact that selection process is still affected by individual views of the employers and their perception of what qualifications a candidate should possess for a certain vacancy (Nickson, 2013), we investigated utilization of selection techniques between different hotel rating categories in Belgrade city region. The assumption is that the higher-ranking hotels have a better selection process, both in terms of quantity (i.e. number of techniques used) and quality (i.e. choice of more sound techniques).

\section{METHODOLOGY}

In order to study the effectiveness of selection process in the hospitality sector in the Republic of Serbia, a survey and oneto-one interview with employees from the human resources department was carried out. Three different hotel rating categories in Belgrade city region were selected, namely three-stars, four-stars and five-stars. In each category, three to four hotels were surveyed, which amounts to a total of 10 hotels examined in early 2015. For the purpose of confidentiality, hotels were not presented by name but were assigned symbols (letters) in alphabetical order, from "A" to "J", respectively. 
Methodological approach applied in this study was quantitative statistical analysis. The main goal of the study was to investigate the occurrence of selection techniques used during the hiring process between the three aforementioned hotel categories. The study design leads to dichotomous answers to the questions in survey. A total of 20 different selection choices was offered regarding two distinct groups of candidates: non-management and management staff. Due to the fact that the sample size was small, i.e. number of hotels that were surveyed within the each rating category, a non-parametric statistical analysis of ranks of the techniques used during the selection process was carried out. This includes One-Sample Kolmogorov-Smirnov Test and Chi-squared based test.

\section{RESULTS AND DISCUSSION}

In order to understand the discrepancies between the selection procedures carried out by different hotel categories, it is important to define the concept of hotel rating. Today, it refers to a more holistic approach with guests' experience of the hotel as a whole (Hensens et al., 2010). However, the Republic of Serbia with its unique cultural and national traditions relies on the state bodies to develop a rating system, according to exterior and interior appearance, accommodation units, types of restaurants, quality of service, as well as the additional units, features and services (Službeni glasnik Republike Srbije, 2010-2012). As the services and features of the hotel increases, so does the category of the hotel, which subsequently increases the demand for highly-qualified and trained staff. Consequently, this results in a more serious hiring process developed by higher ranked hotels.
Data analysis shows a statistically significant difference between the selection techniques used by the hotels of different categories. Three and four-star hotels proved to be similar in applying the range of given selection choices, with "knowledge and background questions" and "one-on-one interviews" being the prevailing techniques used by HR staffing specialists. However, five-star hotels proved distinct from the previous two categories of hotels, both in terms of the number of selection choices used and their frequency of appearance (Table 1).

The analysis of different selection methods used for hiring two distinct groups of candidates was also performed. Nonparametric Chi-square analysis showed a statistically significant difference: a) between selection methods for non-management candidates with the level of significance of 0.05 , b) between selection methods for management candidates with the level of significance of 0.20 . Methods, representing groups of data consisted of tests, interviews and assessment centers, where each one was assigned a number of various selection techniques.

There are significant discrepancies in selection methods used by different hotel categories. Furthermore, non-management group shows the higher level of significance, meaning that utilization of selection methods is even more different for this group of candidates, thus making the whole selection process more distinct between different hotel ratings.

It is obvious that all three methods of selection are conducted by hotels to a various degree, while tests are utilized to a smaller extent. The rationale behind is not clear as tests represent a quick and effective means of assessing a particular individual characteristics with increased reliability and validity due to its multiple items nature (Spector, 2008). One viable explanation is that the

\begin{tabular}{|c|c|c|c|c|c|c|c|c|c|c|c|c|c|c|c|c|c|c|c|c|c|}
\hline \multirow{2}{*}{$\begin{array}{l}\text { Management } \\
\text { Hotel name }\end{array}$} & \multicolumn{10}{|c|}{ Hotel category } & \multicolumn{4}{|l|}{ Non-management } & \multicolumn{7}{|c|}{ Hotel category } \\
\hline & A & B & $\mathrm{C}$ & $\mathrm{D}$ & $\mathrm{E}$ & $\mathrm{F}$ & G & $\mathrm{H}$ & I & $\mathrm{J}$ & Hotel name & A & B & $\mathrm{C}$ & $\mathrm{D}$ & $\mathrm{E}$ & $\mathrm{F}$ & G & $\mathrm{H}$ & I & $\mathrm{J}$ \\
\hline Selection technique & \multicolumn{3}{|c|}{$3^{\star}$ hotels } & \multicolumn{4}{|c|}{$4^{*}$ hotels } & \multicolumn{3}{|c|}{$5^{\star}$ hotels } & Selection technique & \multicolumn{3}{|c|}{$3^{*}$ hotels } & \multicolumn{4}{|c|}{$4^{*}$ hotels } & \multicolumn{3}{|c|}{$5^{*}$ hotels } \\
\hline "Inteligence tests" & - & - & $\sqrt{ }$ & - & - & - & - & - & $\sqrt{ }$ & - & "Inteligence tests" & - & - & $\sqrt{ }$ & - & - & - & - & - & - & - \\
\hline "Psychomotor ability tests" & - & - & - & - & - & - & - & - & $\sqrt{ }$ & - & "Psychomotor ability tests" & - & - & $\sqrt{ }$ & - & - & - & $\sqrt{ }$ & $\sqrt{ }$ & - & - \\
\hline "Knowledge and skills tests" & - & - & $\sqrt{ }$ & - & - & - & $\sqrt{ }$ & - & $\sqrt{ }$ & $\sqrt{ }$ & "Knowledge and skills tests" & - & - & $\sqrt{ }$ & - & - & - & - & $\sqrt{ }$ & $\sqrt{ }$ & - \\
\hline "Personality tests" & - & - & $\sqrt{ }$ & - & - & - & $\sqrt{ }$ & - & $\sqrt{ }$ & - & "Personality tests" & - & - & $\sqrt{ }$ & - & - & - & - & - & - & - \\
\hline EQ tests & - & - & $\sqrt{ }$ & - & - & - & - & - & $\sqrt{ }$ & - & EQ tests & - & - & $\sqrt{ }$ & - & - & - & - & - & $\sqrt{ }$ & - \\
\hline Integrity tests & - & - & $\sqrt{ }$ & - & - & - & $\sqrt{ }$ & - & $\sqrt{ }$ & - & Integrity tests & - & - & $\sqrt{ }$ & - & - & - & - & - & - & - \\
\hline Drug tests & - & - & - & - & - & - & - & - & $\sqrt{ }$ & - & Drug tests & - & - & - & - & - & - & - & - & - & - \\
\hline "Structured interviews" & - & $\sqrt{ }$ & $\sqrt{ }$ & - & - & - & $\sqrt{ }$ & - & $\sqrt{ }$ & $\sqrt{ }$ & "Structured interviews" & - & $\sqrt{ }$ & $\sqrt{ }$ & - & $\sqrt{ }$ & $\sqrt{ }$ & $\sqrt{ }$ & - & $\sqrt{ }$ & $\sqrt{ }$ \\
\hline "Non-structured interviews" & $\sqrt{ }$ & - & - & $\sqrt{ }$ & $\sqrt{ }$ & $\sqrt{ }$ & $\sqrt{ }$ & $\sqrt{ }$ & - & $\sqrt{ }$ & "Non-structured interviews" & $\sqrt{ }$ & - & - & $\sqrt{ }$ & - & - & $\sqrt{ }$ & $\sqrt{ }$ & - & $\sqrt{ }$ \\
\hline "Situational questions" & $\sqrt{ }$ & $\sqrt{ }$ & $\sqrt{ }$ & $\sqrt{ }$ & - & - & $\sqrt{ }$ & $\sqrt{ }$ & $\sqrt{ }$ & $\sqrt{ }$ & "Situational questions" & $\sqrt{ }$ & $\sqrt{ }$ & $\sqrt{ }$ & - & $\sqrt{ }$ & $\sqrt{ }$ & $\sqrt{ }$ & $\sqrt{ }$ & $\sqrt{ }$ & $\sqrt{ }$ \\
\hline "Behavioral questions" & $\sqrt{ }$ & $\sqrt{ }$ & $\sqrt{ }$ & $\sqrt{ }$ & - & - & $\sqrt{ }$ & $\sqrt{ }$ & $\sqrt{ }$ & $\sqrt{ }$ & "Behavioral questions" & $\sqrt{ }$ & $\sqrt{ }$ & $\sqrt{ }$ & $\sqrt{ }$ & $\sqrt{ }$ & - & $\sqrt{ }$ & $\sqrt{ }$ & $\sqrt{ }$ & - \\
\hline Knowledge and background q. & $\sqrt{ }$ & $\sqrt{ }$ & $\sqrt{ }$ & $\sqrt{ }$ & $\sqrt{ }$ & $\sqrt{ }$ & $\sqrt{ }$ & $\sqrt{ }$ & $\sqrt{ }$ & $\sqrt{ }$ & Knowledge and background q. & $\sqrt{ }$ & $\sqrt{ }$ & $\sqrt{ }$ & $\sqrt{ }$ & $\sqrt{ }$ & $\sqrt{ }$ & $\sqrt{ }$ & $\sqrt{ }$ & $\sqrt{ }$ & $\sqrt{ }$ \\
\hline "One-on-one interviews" & $\sqrt{ }$ & $\sqrt{ }$ & $\sqrt{ }$ & $\sqrt{ }$ & $\sqrt{ }$ & $\sqrt{ }$ & $\sqrt{ }$ & $\sqrt{ }$ & $\sqrt{ }$ & $\sqrt{ }$ & "One-on-one interviews" & $\sqrt{ }$ & $\sqrt{ }$ & $\sqrt{ }$ & $\sqrt{ }$ & $\sqrt{ }$ & $\sqrt{ }$ & $\sqrt{ }$ & $\sqrt{ }$ & $\sqrt{ }$ & $\sqrt{ }$ \\
\hline "Sequential interviews" & - & - & $\sqrt{ }$ & $\sqrt{ }$ & $\sqrt{ }$ & $\sqrt{ }$ & $\sqrt{ }$ & $\sqrt{ }$ & $\sqrt{ }$ & $\sqrt{ }$ & "Sequential interviews" & - & - & $\sqrt{ }$ & $\sqrt{ }$ & $\sqrt{ }$ & $\sqrt{ }$ & $\sqrt{ }$ & $\sqrt{ }$ & $\sqrt{ }$ & $\sqrt{ }$ \\
\hline "Panel interviews" & - & - & - & - & $\sqrt{ }$ & $\sqrt{ }$ & $\sqrt{ }$ & $\sqrt{ }$ & $\sqrt{ }$ & $\sqrt{ }$ & "Panel interviews" & - & - & - & - & $\sqrt{ }$ & - & - & - & - & $\sqrt{ }$ \\
\hline Video or phone interview & - & - & - & - & - & - & - & $\sqrt{ }$ & - & - & Video or phone interview & - & - & - & - & - & - & - & - & - & $\sqrt{ }$ \\
\hline The in-basket & - & - & $\sqrt{ }$ & - & - & $\sqrt{ }$ & $\sqrt{ }$ & - & $\sqrt{ }$ & - & The in-basket & - & - & $\sqrt{ }$ & - & - & $\sqrt{ }$ & $\sqrt{ }$ & - & $\sqrt{ }$ & - \\
\hline "The leaderless group discussion" & - & - & $\sqrt{ }$ & - & - & - & - & - & $\sqrt{ }$ & - & "The leaderless group discussion" & - & - & - & - & - & - & - & - & $\sqrt{ }$ & - \\
\hline "Problem-solving simulation" & - & - & $\sqrt{ }$ & - & - & - & $\sqrt{ }$ & - & $\sqrt{ }$ & - & "Problem-solving simulation" & - & - & $\sqrt{ }$ & - & - & - & - & - & $\sqrt{ }$ & - \\
\hline Role play & - & - & $\sqrt{ }$ & - & - & - & $\sqrt{ }$ & - & $\sqrt{ }$ & - & Role play & - & - & $\sqrt{ }$ & - & $\sqrt{ }$ & - & - & $\sqrt{ }$ & $\sqrt{ }$ & - \\
\hline
\end{tabular}

Table 1. Selection techniques utilized by different rating hotel categories 
tests are generally used in hospitality to assess knowledge of hotel operations, with particular reference to the area of candidates' future work (Barjaktarović, 2013). Obviously, further research is required to elucidate this phenomenon.

Assessment centre occurs randomly and does not show great variability between different hotel ratings. However, it seems that only one of the surveyed hotels in each category regularly practice it, which can be associated with relative unfamiliarity with this selection method in the hotel industry and/ or high level of HR expertise and time/effort consumption in performing it. Considering that the assessment centre is a good predictor of future job performance (Spector, 2008), hotels shall make every effort to develop a high level of realism and train HR specialist to effectively carry out this battery of exercises.

Interviews seem to be the most frequent means of assessing candidates, but hotels are applying a random variety of selection techniques. The most prominent are one-on-one interviews with an emphasis on knowledge and background questions that are present in almost all categories of the surveyed hotels. This fits to a certain degree an emphasis on the previous experience that seems to be important for hotel industry, which provides intangible products such as quality of service to the customers. However, structured and non-structured interviews bear a close resemblance, despite the fact that an unstructured interview, casual and made up of random questions that allows for a number of biases, has been proven to be less effective selection device (Robbins, 2005). It is similar to behavioural and situational interviews, none of which seems to be the dominant way of assessing candidates and depends more on the occurrence as usual HR practice in a particular hotel rather than selection technique that proved more suitable for certain vacancies.

\section{SUMMARY}

The aim of this paper was to investigate utilization of selection techniques between different rating hotel categories in Belgrade city region. It is well-known in services industry, such as hospitality, that effective utilization of human capital can give a competitive advantage to an organization (Schneider and Bowen, 1993). However, hotel industry is exposed to high staff turnover that constantly threatens human capital value, as the essence of the business, with a clear goal of minimizing turnover through proper hiring process (Cheng and Brown, 1998).

Research shows a significant difference between the selection techniques used by the hotels of different categories. Top ranking hotels (i.e. five-stars) place greater emphasis on the hiring process, while applying a wider range of selection techniques to differentiate job candidates. Of all the methods used by the surveyed hotels for the selection process, an interview seems to be the most frequently used one. Tests and assessment centre are used randomly, mainly by a particular hotel(s) within each category, which seems to be a peculiar characteristic concerning HR practice and expertise of a certain hotel.

Further in-depth research is required in order to determine the most effective selection techniques required for proper em- ployee hiring. Taking in consideration the high costs of contemporary staffing (CIPD, 2009) and the value of employee services for the sustainable hospitality business, the impact of selection methods cannot be underestimated.

\section{REFERENCES}

Barjaktarović, D. (2013). Upravljanje kvalitetom u hotelijerstvu. Beograd: Univerzitet Singidunum.

Bhutoria, N. (2006). Valuation of Human Capital. Retrieved from www.hrfolks.com/articles/intellectual\%20capital/valuation\%20of\%20human\%20capital.pdf

Cheng, A., \& Brown, A. (1998). HRM strategies and labor turnover in the hotel industry: A comparative study of Australia and Singapore. International Journal of Human Resource Management, 9(1), p. 136-154.

CIPD. (2009). Annual Survey Report 2009. Recruitment, Retention and Turnover. Retrieved from http://www.cipd.co.uk/binaries/recruitment_retention_turnover_annual_survey_2009. pdf

Dessler, G. (2012). Selecting Employees. In: Fundamentals of Human Resource management ( $2^{\text {nd }}$ edition). New Jersey Pearson Education, pp. 146-180.

Hensens, W., Srugwig, M., \& Dayan, O. (2010). Guest-Review Criteria on TripAdvisor Compared to Conventional HotelRating Systems to Assess Hotel Quality, in: Passion for Hospitality Excellence: European Council on Hotel, Restaurant \& Institutional Education, 2010 Conference Proceedings, pp. 1-12.

Nickson, D. (2013). Human Resource Management for Hospitality, Tourism and Events. Hoboken: Taylor and Francis, pp. 106.

Noe, R.A., Hollenbeck, J.R., Gerhart, B., \& Wright, P.M. (2007). Selecting Employees and Placing them in Jobs, in: Fundamentals of Human Resource Management. New York: McGraw-Hill, pp. 174-207.

Ocean Tomo. (2010). Intangible Asset Market Value Study. Retrieved from http://www.oceantomo.com/

Robbins, S. (2005). Human Resource Policies and Practices. In: Essentials of Organizational Behavior ( $8^{\text {th }}$ edition). New Jersey: Pearson Prentice Hall, pp. 247-263.

Schneider, B., \& Bowen, D.E. (1993). The Service Organization: Human Resource Management is Crucial. Organizational Dynamics, 21(4): 39-52.

Služebni glasnik Republike Srbije. (2012). Pravilnik o standardima za kategorizaciju ugostiteljskih objekata za smeštaj. Retrieved from http://www.beograd.rs/download.php/documents/pravilnikostandardima.pdf

Spector, P. (2008). Assessment Methods for Selection and Placement, in: Industrial and Organizational Psychology. Hoboken: John Wiley \& Sons, pp. 108-137.

Torrington, D., Hall, L., Taylor, S., \& Atkinson C. (2014). Selection Methods and Decisions, in: Human Resource Management. Harlow : Pearson Education, pp. 132-152. 